ORIGINAL ARTICLE

\title{
Evaluation of the antioxidant potential of Copaifera multijuga in Ehrlich tumor-bearing mice
}

\author{
Ana Paula Simões da CUNHA ${ }^{1}$, Luana BALDISSERA ${ }^{1}$, Débora Linsbinski PEREIRA², Lucineia Reuse ALBIERO ${ }^{1}$, \\ Lindsey CASTOLDI ${ }^{1}$, Adilson Paulo SINHORIN ${ }^{2}$, Valéria Dornelles Gindri SINHORIN²* \\ Universidade Federal de Mato Grosso, Instituto de Ciências da Saúde, Campus de Sinop, Sinop, Mato Grosso, Brazil \\ 2 Universidade Federal de Mato Grosso, Instituto de Ciências Naturais, Humanas e Sociais, Programa de Pós Gradução em Ciências Ambientais (PPGCAM), \\ Laboratórios Integrados de Pesquisas em Ciências Químicas (LIPEQ), Campus de Sinop, Sinop, Mato Grosso, Brazil \\ * Corresponding author: valeriadgindri@gmail.com
}

\begin{abstract}
Copaifera multijuga, commonly known as copaiba, is popularly used in the form of tea for various conditions due to the presence of antioxidant substances in its composition, which protect cells against damage caused by free radicals. Its oleoresin is also used as an anti-inflammatory and antitumoral agent. The present study investigated the antioxidant effect of the ethanolic extract of copaiba stem bark on Swiss mice inoculated with solid Ehrlich tumors. Mice were inoculated subcutaneously with $1 \times 10^{6}$ Ehrlich's tumor cells and treated via gavage with ethanolic extract of copaiba for thirty days, with doses varying between 100 and $200 \mathrm{mg} \mathrm{kg}^{-1}$. Biochemical analyses of enzymatic antioxidants [superoxide dismutase (SOD), catalase (CAT), glutathioneS-transferase (GST)], non-enzymatic antioxidants [reduced glutathione (GSH) and ascorbic acid (ASA)], substances reactive to thiobarbituric acid (TBARS) and protein carbonylation (carbonyl) in different tissues were significantly affected. The extract administered at $200 \mathrm{mg} \mathrm{kg}^{-1}$ presented higher antioxidant capacity in the liver, increased CAT, GST, GSH and decreased TBARS, as well as increased CAT activity and protein carbonylation in brain tissue. The results showed that the copaiba extract was able to reverse the oxidative stress caused by solid Ehrlich tumor, probably due to the presence of antioxidant compounds, and had potential antineoplasic effect after a 30-day treatment.
\end{abstract}

KEYWORDS: solid tumor, oxidative stress, free radicals, copaiba, antineoplasic

\section{Avaliação do potencial antioxidante de Copaifera multijuga em camundongos com tumor de Ehrlich}

\section{RESUMO}

Copaifera multijuga, ou copaíba, é utilizada popularmente como chá para o tratamento de diversas afecçóes, o que se deve à presença de substâncias antioxidantes em sua composição, que protegem as células contra danos causados pelos radicais livres. $\mathrm{O}$ óleo-resina da árvore é usado como antiinflamatório e antitumoral. O presente estudo avaliou o efeito antioxidante do extrato etanólico da casca da copaíba sobre camundongos Swiss machos inoculados com tumor sólido de Ehrlich. Os camundongos foram inoculados subcutaneamente com $1 \times 10^{6}$ células de tumor de Ehrlich e foram tratados, via gavagem durante 30 dias, com doses de extrato etanólico de copaíba variando de 100 a $200 \mathrm{mg} \mathrm{kg}^{-1}$. Realizou-se análise bioquímica dos antioxidantes enzimáticos [superóxido dismutase (SOD), catalase (CAT), glutationa-S-transferase (GST)], antioxidantes não-enzimáticos [glutationa reduzida (GSH) e ácido ascórbico (ASA)], substâncias reativas ao ácido tiobarbitúrico (TBARS) e carbonilação proteica (carbonil) em diferentes tecidos e apresentando resultados significativos. O extrato administrado na concentração de $200 \mathrm{mg} \mathrm{kg}^{-1}$ apresentou melhor capacidade antioxidante no fígado, aumentando a CAT, GST, GSH e diminuindo TBARS, além de aumentar a atividade da CAT e da carbonilaçáo proteica no tecido cerebral. Os resultados mostram que o extrato de copaíba foi capaz de reverter o estresse oxidativo causado pelo tumor sólido de Ehrlich, provavelmente por conter compostos antioxidantes, e possivelmente teve um efeito antineoplásico após 30 dias de tratamento.

PALAVRAS-CHAVE: tumor sólido, estresse oxidativo, radicais livres, copaíba, antineoplásico 


\section{INTRODUCTION}

The increasing incidence of cancer in the world calls for the continuous search for new treatments that are both efficient and cause minimal side effects to normal cells. This includes the research on active components in plants, and the development of phytopharmaceuticals with anticancer activity (Loaces and Cabrera 2003).

The trees of the genus Copaifera are popularly known in Brazil as copaíba, with 26 species distributed throughout north and northeastern Brazil (Costa 2018). Copaiba oleoresin, which is extracted from the trunk of the tree and is rich in terpene compounds, including sesquiterpenes and diterpenes, is very popular as a medicinal plant compound in northern Brazil (Veiga and Pinto 2002; Santiago et al. 2015; Silva et al. 2017; Furtado et al. 2018). The oleoresin of 17 species of Copaifera has been chemically studied (Veiga et al. 2007; Gramosa et al. 2010; Leandro et al. 2012), and has been described as having anticancer activities (Gomes et al. 2008), antiparasitic activity against Chagas disease (Izumi et al. 2012), and anti-inflammatory and neuroprotective activity (Guimarães-Santos et al. 2012). The leaf extract has protective effects against colon carcinogenesis (Senedese et al. 2013), as well as antioxidant activity and neuroprotective effects (Botelho et al. 2015).

Copaifera multijuga Hayne (Fabaceae, Caesalpinoidae) is a copaíba species endemic to the Amazon region (Costa 2018; Furtado et al. 2018). The oleoresin of C. multijuga has long been explored by indigenous and traditional Amazonian peoples by tapping the trunk to obtain the exuded oleoresin, which is used as an anti-inflammatory and wound-healing agent, as an urinary antiseptic, and to treat ulcers, bronchitis and tumors (Veiga and Pinto 2002). The leaves of C. multijuga, which are used as tea, are rich in phenolic compounds (Pereira et al. 2018), including two flavonoid heterosides and 16 galloylquinic acid derivatives (Furtado et al. 2018), which are compounds with strong antioxidant potential. In vitro and in vivo tests have shown that the ethanolic stem bark extract of C. multijuga reduces tumor growth at a concentration of 200 $\mathrm{mg} \mathrm{kg}^{-1}$ (Albiero et al. 2016).

Antioxidant compounds have an important role in the metabolism of oxidative stress, which has been implicated in the development of neurodegenerative diseases, epileptic seizures, aging, and the promotion of certain types of cancer (Pinent et al. 2006). Oxidative stress is involved in carcinogenesis due to the generation of reactive oxygen species (ROS) (Noda and Wakasugi 2000). Several human tumors, including melanoma, leukemia, gastric, prostatic, mammary and colon carcinomas, have high levels of ROS (Reuter et al. 2010). ROS are molecules formed during mitochondrial respiration that play important roles in cellular signaling (Kronek and Sosa-Torres 2015). They originate from endogenous or exogenous sources, and trigger biochemical reactions which lead to the formation of new reactive molecules that are capable of attacking membranes and other cell parts (Lushchak 2014). ROS are produced naturally in our bodies through oxidative metabolic processes, important as effector mechanisms of immune system cells (Schneider and Oliveira 2004). The increased production of ROS during oxidative stress, such as the formation of superoxide and hydroxyl radicals during pathophysiological conditions, reduces the generation of antioxidant resources, unbalancing and harming healthy tissues, and leading to lipid peroxidation (Grivennikov et al. 2010).

The Ehrlich tumor method is an efficient tool in the evaluation of the antioxidant effect of test compounds on carcinom development in animal models is. Ehrlich's tumor is a spontaneous murine mammary adenocarcinoma adapted to ascitic form and carried in mice by serial intraperitoneal passages (Cassali et al. 2006; Calixto-Campos et al. 2013). This tumor was described for the first time by Ehrlich and Apolant (1905) and is used for testing antineoplastic drugs, cancer pain and cachexia (Calixto-Campos et al. 2013; Frajacomo et al. 2016; Albiero et al. 2016). The Ehrlich's tumor model is widely used in experimental cancer studies due to its versatility. It evolves into an ascitic form when inoculated by intraperitoneal route, and into a solid form when inoculated subcutaneously, and is able to grow in any type of mice (Calixto-Campos et al. 2013; Albiero et al. 2016; Frajacomo et al. 2016).

Considering the known presence of antioxidant compounds in C. multijuga leaves and bark, its traditional use for treatment of tumors in popular medicine, and the findings by Albiero et al. (2016) that copaiba stem bark extract was able to interfere in the development of tumor cells as well as their viability, we hypothesized that the antioxidants present in the extract (Pereira et al. 2018) may interfere in the generation of oxygen reactive species produced by the Ehrlich tumor. Thus, our objective was to evaluate the ethanolic extract of $C$. multijuga stem bark for possible antioxidant and antineoplasic effects on Ehrlich tumor-bearing mice using three extract concentrations.

\section{MATERIAL AND METHODS}

\section{Collection and extract preparation}

Stem bark of Copaifera multijuga was collected from one tree in the city of Guarantã do Norte (Mato Grosso state, Brazil) (948'31.0"S, 5453'18.0”W). Voucher specimens were deposited in the Herbarium of the Federal University of Mato Grosso (UFMT), Sinop campus, under registration number 4801. The samples were dried and milled for extraction of the ethanolic extract (Albiero et al. 2016) for the in vivo test.

\section{In vivo test procedures}

Male Swiss mice with an average weight of $45 \mathrm{~g}$ were obtained from the Central Animal Facility at Federal University of Mato 
Grosso (UFMT) and were kept in controlled conditions of temperature $\left(22 \pm 20^{\circ} \mathrm{C}\right)$, relative humidity $(55 \pm 10 \%)$, light (12 hours light / dark), and received commercial pelleted feed (Purina, Brazil) and filtered water ad libitum. All procedures were conducted in accordance with the recommendations of the Brazilian College of Animal Experimentation and were approved by the Ethics Committee on Animal Use (Comitê de Ética no Uso de Animais - CEUA) of Federal University of Mato Grosso (UFMT) (CEUA Protocol no 23108.700603/14-3).

The animals were acclimated for 14 days, and were then divided into four groups of eight animals per group. All animals were inoculated subcutaneously with $1 \times 10^{6}$ Ehrlich tumor cells. After 24 hours, the control group (C) started to receive phosphate buffer saline (PBS). Three treatment levels were determined based on Albiero et al. (2016). Each treatment group received $100 \mathrm{mg} \mathrm{kg}^{-1}, 150 \mathrm{mg} \mathrm{kg}^{-1}$ and 200 $\mathrm{mg} \mathrm{kg}^{-1}$ of ethanolic extract dissolved in PBS, respectively. The solutions were administered intragastrically by gavage (100 $\mu \mathrm{L} /$ animal/day) during 30 consecutive days. After the treatment period, the animals were sacrificed by cervical dislocation and the liver, brain and kidneys were removed. The tissues were stored in an ultra-freezer at $-80{ }^{\circ} \mathrm{C}$.

Ehrlich tumor cells were kindly provided by Dr. Rondon Tosta Ramalho, from Federal University of Mato Grosso do Sul - UFMS, Brazil). Ehrlich tumors were maintained through intraperitoneal inoculation (ascitic form) in Swiss mice, every seven days. Tumor cell suspensions were prepared in sterile PBS to the final concentration of $1 \times 10^{7}$ viable cells $\mathrm{mL}^{-1}$. Mice were inoculated subcutaneously in the right flank region $(0.1 \mathrm{~mL}$ per animal). Viability, assessed by the Trypan Blue dye exclusion method, was always found to be at least $70 \%$.

\section{Biochemical analyses}

In order to assess the effect of the copaíba stem bark extract on the oxidative stress produced by the Ehrlich tumors we determined the levels of up to seven biochemical parameters (enzymatic and non-enzymatic antioxidants and lipid and protein damage biomarkers).

Superoxide dismutase (SOD) activity was assessed in the liver tissue by inhibition of adrenaline oxidation, measured spectrophotometrically at $480 \mathrm{~nm}$, using the UVVIS spectrophotometer according to Misra and Fridovich (1972) and expressed as UI SOD mg protein ${ }^{-1}$. Catalase (CAT) activity was determined in liver, kidney and brain tissue according to Nelson and Kiesow (1972). The principle is based on decomposition of $\mathrm{H}_{2} \mathrm{O}_{2}$ that is measured spectrophotometrically at $240 \mathrm{~nm}$ and expressed in $\mu \mathrm{mol}$ $\mathrm{H}_{2} \mathrm{O}_{2}$ min $^{-1} \mathrm{mg}$ protein ${ }^{-1}$. Glutathione-S-transferase (GST) activity was determined in the liver tissue according to Habig et al. (1974), the enzymatic activity was measured based on the formation of GS-DNB adduct, and the result was expressed in $\mu \mathrm{mol}$ GS-DNB $\mathrm{min}^{-1} \mathrm{mg}$ protein ${ }^{-1}$.

Reduced glutathione (GSH) was measured in liver, kidney and brain tissue using the colorimetric method consisting of a reaction of sulfhydryl groups developed by Sedlak and Lindsay (1968), and quantified at $412 \mathrm{~nm}$. The result was expressed in $\mu \mathrm{mol} \mathrm{GSH} \mathrm{mg} \mathrm{protein}{ }^{-1}$ and compared to a standard GSH curve. Ascorbic acid (ASA, vitamin C) levels in the liver tissue were determined according to Roe (1954) by colorimetric method and read at absorbance of $520 \mathrm{~nm}$. The result was expressed in $\mu \mathrm{mol} \mathrm{ASA} \mathrm{g} \mathrm{g}^{-1}$ of tissue and compared to a standard curve of ascorbic acid.

Lipid peroxidation levels in liver tissue were evaluated according to Buege and Aust (1978) by determining the levels of substances reactive to thiobarbituric acid (TBARS). TBARS concentration was expressed in nmol MDA mg protein $^{-1}$ following the calibration curve for MDA. The protein carbonyl content in liver, kidney and brain was determined by spectrophotometry after DNPH derivation according to Yan et al. (1995), with some modifications. The total carbonyl content was assessed using a molar extinction coefficient of $22.000 \mathrm{M}^{-1} \mathrm{~cm}^{-1}$ and expressed as nmol carbonyl $\mathrm{mg}_{\text {protein }}{ }^{-1}$.

Protein content (except ASA) was estimated by spectrophotometry according to Bradford (1976) using bovine serum albumin as a standard. Absorbance of the samples was measured at $595 \mathrm{~nm}$.

\section{Statistical analysis}

Biochemical parameters were compared among treatments and control using one-way ANOVA, followed by the post hoc Tukey test. The results were considered statistically significant at $P<0.05$.

\section{RESULTS}

In the hepatic tissue, relative to the control, there was a significant increase in SOD activity in the $150 \mathrm{mg} \mathrm{kg}^{-1}$ treatment (Figure 1A), CAT and GST activity in the $200 \mathrm{mg}$ $\mathrm{kg}^{-1}$ treatment (Figure 1B, 1C), and GSH in the $200 \mathrm{mg} \mathrm{kg}^{-1}$ treatment (Table 1). There was no significant difference among groups in ASA levels (Table 1). There was a significant decrease in TBARS in the $200 \mathrm{mg} \mathrm{kg}^{-1}$ treatment (Figure 1A). Protein carbonylation did not differ significantly among groups (Table 1). In renal tissue, there was a significant decrease in GSH in the $100 \mathrm{mg} \mathrm{kg}^{-1}$ treatment in relation to the control, while CAT, ASA and carbonyl did not differ among groups (Table 2). In brain tissue, there was a significant increase in CAT activity in the $200 \mathrm{mg} \mathrm{kg}^{-1}$ treatment, and in carbonyl in the 200 and $100 \mathrm{mg} \mathrm{kg}^{-1}$ treatments, all relative to the control. GSH did not vary significantly among groups (Table 3 ). 

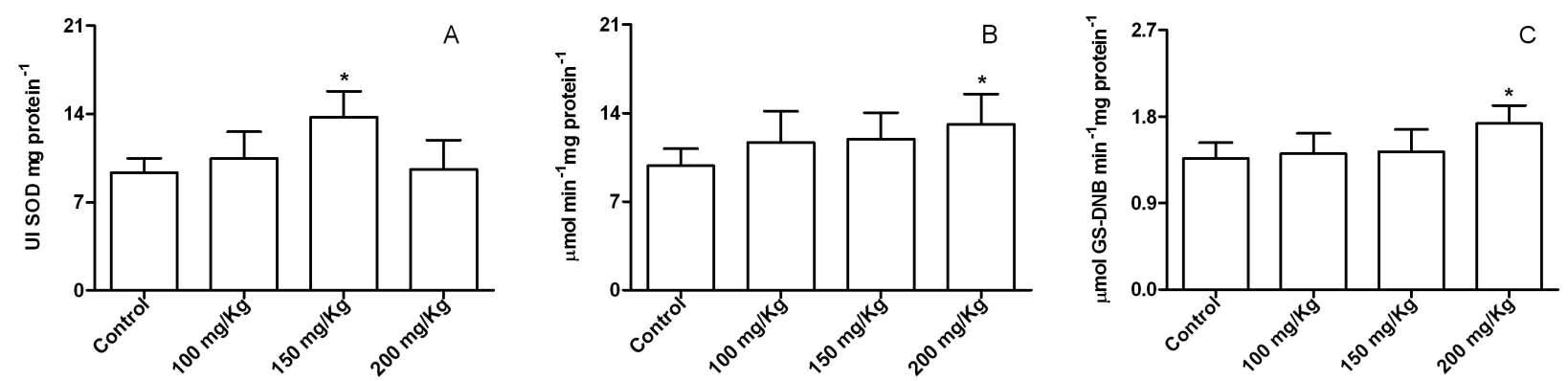

Figure 1. Effect of different concentrations of the ethanolic extract of Copaifera multijuga stem bark on hepatic tissue of mice after 30 days of inoculation with Ehrlich subcutaneous carcinoma, as indicated by SOD (A), CAT (B) and GST (C). Asteriscs indicate significant differences in relation to the control according to ANOVA followed by Tukey test $(P<0.05) ; \mathrm{N}=8$.

Table 1. Effect of different concentrations of the ethanolic extract of Copaifera multijuga stem bark on indicator parameters in hepatic tissue of mice after 30 days of inoculation with Ehrlich subcutaneous carcinoma. Values are the mean \pm standard deviation. Asteriscs indicate significant differences in relation to the control according to ANOVA followed by Tukey test $(P<0.05) ; \mathrm{N}=8$.

\begin{tabular}{|c|c|c|c|c|}
\hline Treatments & $\begin{array}{c}\text { GSH } \\
(\mu \mathrm{mol} \text { GSH } \\
\left.\text { mg protein }^{-1}\right)\end{array}$ & $\begin{array}{c}\text { ASA } \\
(\mu \mathrm{mol} \text { ASA } \\
\left.\mathrm{g}^{-1} \text { tissue }\right)\end{array}$ & $\begin{array}{c}\text { TBARS } \\
(\mathrm{nmol} \mathrm{MDA} \\
\left.\mathrm{mg} \mathrm{protein}^{-1}\right)\end{array}$ & $\begin{array}{c}\text { CARBONYL } \\
\text { (nmol carbonyl } \\
\text { mg protein }^{-1} \text { ) }\end{array}$ \\
\hline Control & $420.7 \pm 88.52$ & $1.254 \pm 0.17$ & $1.175 \pm 0.29$ & $4.600 \pm 0.80$ \\
\hline $100 \mathrm{mg} \mathrm{kg}^{-1}$ & $452.2 \pm 80.11$ & $1.250 \pm 0.07$ & $0.952 \pm 0.14$ & $5.134 \pm 0.89$ \\
\hline $150 \mathrm{mg} \mathrm{kg}^{-1}$ & $359.8 \pm 65.67$ & $1.095 \pm 0.14$ & $1.060 \pm 0.23$ & $4.189 \pm 0.64$ \\
\hline $200 \mathrm{mg} \mathrm{kg}^{-1}$ & $616.4 \pm 130.60^{*}$ & $1.230 \pm 0.09$ & $0.847 \pm 0.13^{*}$ & $5.551 \pm 1.21$ \\
\hline
\end{tabular}

Table 2. Effect of different concentrations of the ethanolic extract of Copaifera multijuga stem bark on indicator parameters in renal tissue of mice after 30 days of inoculation with Ehrlich subcutaneous carcinoma. Values are the mean \pm standard deviation. Asteriscs indicate significant differences in relation to the control according to ANOVA followed by Tukey test $(P<0.05) ; \mathrm{N}=8$.

\begin{tabular}{|c|c|c|c|c|}
\hline Treatments & 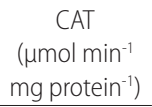 & $\begin{array}{c}\text { GSH } \\
(\mu \mathrm{mol} \text { GSH mg } \\
\left.\text { protein }{ }^{-1}\right)\end{array}$ & $\begin{array}{c}\text { ASA } \\
(\mu \mathrm{mol} \text { ASA } \\
\left.\mathrm{g}^{-1} \text { tissue }\right)\end{array}$ & $\begin{array}{c}\text { CARBONYL } \\
\text { (nmol carbonyl } \\
\text { mg protein }^{-1} \text { ) }\end{array}$ \\
\hline Control & $15.86 \pm 2.04$ & $184.6 \pm 31.76$ & $0.9163 \pm 0.15$ & $8.580 \pm 1.75$ \\
\hline $100 \mathrm{mg} \mathrm{kg}^{-1}$ & $14.93 \pm 3.00$ & $134.1 \pm 28.39^{*}$ & $0.8688 \pm 0.15$ & $7.630 \pm 1.62$ \\
\hline $150 \mathrm{mg} \mathrm{kg}^{-1}$ & $16.40 \pm 1.81$ & $162.4 \pm 39.94$ & $0.8313 \pm 0.12$ & $8.257 \pm 1.54$ \\
\hline $200 \mathrm{mg} \mathrm{kg}^{-1}$ & $16.60 \pm 1.16$ & $140.6 \pm 27.43$ & $0.9025 \pm 0.11$ & $9.088 \pm 1.08$ \\
\hline
\end{tabular}

Table 3. Effect of different concentrations of the ethanolic extract of Copaifera multijuga stem bark on indicator parameters in brain tissue of mice after 30 days of inoculation with Ehrlich subcutaneous carcinoma. Values are the mean \pm standard deviation. Asteriscs indicate significant differences in relation to the control according to ANOVA followed by Tukey test $(P<0.05)$; $N=8$.

\begin{tabular}{|c|c|c|c|}
\hline Groups & $\begin{array}{c}\text { CAT } \\
\left(\mu \mathrm{mol} \mathrm{min}^{-1} \mathrm{mg}\right. \\
\left.\text { protein }{ }^{-1}\right)\end{array}$ & $\begin{array}{c}\text { GSH } \\
(\mu \mathrm{mol} \text { GSH mg } \\
\left.\text { protein }^{-1}\right) \\
\end{array}$ & $\begin{array}{c}\text { CARBONYL } \\
\text { (nmol carbonyl mg } \\
\left.\text { protein }^{-1}\right)\end{array}$ \\
\hline Control & $1.224 \pm 0.30$ & $452.8 \pm 98.35$ & $4.348 \pm 0.89$ \\
\hline $100 \mathrm{mg} \mathrm{kg}^{-1}$ & $1.610 \pm 0.36$ & $448.5 \pm 109.70$ & $6.503 \pm 1.57^{*}$ \\
\hline $150 \mathrm{mg} \mathrm{kg}^{-1}$ & $1.513 \pm 0.30$ & $440.2 \pm 95.55$ & $3.648 \pm 0.73$ \\
\hline $200 \mathrm{mg} \mathrm{kg}^{-1}$ & $2.156 \pm 0.14^{*}$ & $423.1 \pm 42.61$ & $6.092 \pm 1.57^{*}$ \\
\hline
\end{tabular}

\section{DISCUSSION}

Several human tumors present high levels of reactive oxygen species (ROS) (Reuter et al. 2010). Although, ROS are produced naturally in the body through oxidative metabolic processes, they are also important as effector mechanisms of the cells of the immune system (Schneider and Oliveira 2004). In this context, the immune system is activated through the inoculation of mice with Ehrlich tumor. The continuous production of free radicals during metabolic processes has led to the development of many antioxidant defense mechanisms to limit and prevent cell damage (Vasconcelos et al. 2014). The antioxidants present in the C. multijuga stem bark extract (Pereira et al. 2018) may be interfering in the generation of oxygen reactive species produced by the Ehrlich tumor.

SOD is considered one of the most important enzymes in the antioxidant process (Ighodaro and Akinloye 2017). In Ehrlich ascitic tumor-bearing mice a decrease in the activitiy of SOD, CAT and GSH occurs, as well as an increase in malondialdehyde levels, the end product of lipid peroxidation (Samudrala et al. 2015). In our study, the copaiba extract at $150 \mathrm{mg} \mathrm{kg}^{-1}$ was able to reverse the oxidative stress caused by the Ehrlich tumor, increasing SOD activity in the liver. At $200 \mathrm{mg} \mathrm{kg}^{-1}$ the activity of CAT and GST increased, and TBARS decreased. The increased activity of these enzymes in presence of oxidative stress is an adaptive response, aiming at detoxifying the organism of oxygen free radicals and prevent damage to macromolecules (Ballesteros et al. 2009). The ethanolic extract of $C$. multijuga stem bark is rich in antioxidants, containing a high concentration $\left(250 \mathrm{mg} \mathrm{kg}^{-1}\right)$ of total phenols and flavonoids, more specifically phenolic compounds in the form of tannins (Pereira et al. 2018). Rajeshwar et al. (2005) obtained similar results with mice inoculated intraperitoneally with $2 \times 10^{6}$ Ehrlich tumor cells and treated for 14 days with 125 and $250 \mathrm{mg} \mathrm{kg}^{-1}$ methanolic extract of Mucuna pruriens (Fabaceae).

Our results for increased CAT activity in the liver are in accordance with Ali et al. (2015), who observed an increase of CAT in the liver and blood of tumor-inoculated mice fed grape 
bark and seed supplemented diet for 30 days. This supports our results, suggesting that copaiba bark extract, when administered for 30 days, has a positive effect on the damage generated by Ehrlich tumor, probably by helping to remove ROS.

GST is the enzyme responsible for the xenobiotic detoxification of the organism, and promotes protection against electrophilic compounds and oxidative stress products (Nathiya and Nandhini 2014). Our results for increased GST activity agree with Bhattacharya $e$ t al. (2011), who inoculated mice intraperitoneally with $2 \times 10^{6}$ Ehrlich tumor cells and treated them for 9 days with 5 and $10 \mathrm{mg} \mathrm{kg}^{-1}$ ethanolic extract of Trichosanthes dioica root, showing that this dose was one of the most effective against oxidative stress generated by tumor growth, increasing both CAT and GST.

GSH is the only non-protein thiol and an important non-enzymatic antioxidant in the process of keeping the body in homeostasis against free radicals and detoxifying xenobiotics, and performs an important role as coenzyme to GST and glutathione peroxidase (GPx) (Goulart et al. 2007). Although GSH decreased in renal tissue with lowest extract concentration, the increase of GSH in hepatic tissue at 200 $\mathrm{mg} \mathrm{kg}^{-1}$ of extract suggests that, at the highest concentration tested, the copaiba extract might have a protective effect, probably due to its high concentration of tannins (Pereira et al. 2018), which can interfere positively with some antioxidants in the liver. Ali et al. (2015) also observed an increase of GSH in hepatic tissue.

Lipid peroxidation (TBARS) occurs through malondialdehyde, a physiological acetaldehyde produced by the decomposition of unsaturated lipids from the metabolism of arachidonic acid, and its excess can lead to tissue damage, in addition to the carbonylation of proteins, that can form carbonyl compounds, a general marker used to prove the severe oxidation of proteins (Sellés et al. 2016). The decrease in TBARS in hepatic tissue in the $200 \mathrm{mg} \mathrm{kg}^{-1}$ treatment indicated that there was no increase in lipid peroxidation, and the extract reduced the damage caused by the tumor. Ali et al. (2015) and Bhattacharya et al. (2011) also observed a decrease in lipid peroxidation in hepatic tissue. Protein carbonylation was not altered in the liver and kidney in our study. Although carbonylation increased in brain tissue at the lowest and highest treatment dose, the increase in CAT in the brain suggests that the extract compounds may act to some extent to protect against damage in this tissue.

Overall, our results suggest that the treatment with copaiba stem bark extract is able to reverse the pro-oxidant effect induced by the Ehrlich tumor, improving the antitumor immune response, supporting the results of Samudrala et al. (2015) and Albiero et al. (2016), who showed that the ethanolic extract of copaiba bark is able to reduce the viability of Ehrlich tumor cells in vitro, as well as their development in vivo.
The cellular proliferation of tumors is inversely proportional to lipid peroxidation and is involved in the decrease of GPx and GST activity (Das et al. 2014). The decrease in TBARS and the increase in GST in the liver of mice treated with $200 \mathrm{mg} \mathrm{kg}^{-1}$ of copaiba thus indicates that this dose was effective in hepatic tissue, as it affected most of the evaluated parameters. Decreased SOD, CAT, and tumor-related GSH concentrations are considered malignant transformation markers (Kavitha and Manoharan 2006), therefore our results for GSH and CAT in the $200 \mathrm{mg} \mathrm{kg}^{-1}$ treatment equaly suggest that the copaiba extract protected the animals from the damage by the Ehrlich tumor at the highest test dose.

Albiero et al. (2016) used the same experimental model and found reduced tumor growth in mice treated with copaiba extract at a concentration of $200 \mathrm{mg} \mathrm{kg}^{-1}$. The same study also evaluated ex vivo cytokine production in ConA or SACstimulated spleen cell culture supernatants, resulting in an increase of IL-12p70, TNF- $\alpha$ and IFN- $\gamma$ in mice treated for seven days with the $200 \mathrm{mg} \mathrm{kg}^{-1}$ copaiba ethanolic extract, demonstrating a proinflammatory profile in response to the immune system against the tumor. Our results support these authors in that copaiba stem bark extract contains compounds that act as biological response modifiers.

\section{CONCLUSIONS}

Our results showed that a concentration of $200 \mathrm{mg} \mathrm{kg}^{-1}$ of ethanolic extract of Copaifera multijuga stem bark administered during 30 days had significant effects on some biomarkers of oxidative stress in in vivo models inoculated with Ehrlich tumor cells, suggesting that this plant part contains substances capable of reducing the damage generated by free radicals. This is the first study to evaluate the pharmacological potential of $C$. multijuga stem bark extract. Future research should further explore the phytochemical potential of $C$. multijuga stem bark compounds.

\section{ACKNOWLEDGMENTS}

The authors express their gratitude to Coordenação de Aperfeiçoamento de Pessoal de Nível Superior (CAPES) and Fundação de Amparo à Pesquisa do Estado de Mato Grosso (FAPEMAT) for granting scholarships to D. L. Pereira and A. P. S. Cunha, respectively.

\section{REFERENCES}

Albiero, L.R.; Nery, E.F.; Dalazen, J.C.; Kelly, T.O.; Pereira, D.L.; Sinhorin, V.D.G.; Kaneno, R.; Castoldi, L. 2016. Ethanolic extracts of Copaifera multijuga inhibits the subcutaneous growth of Ehrlich carcinoma is Swiss mice. Journal of Pharmacy and Biological Sciences, 11: 30-38.

Ali, A.A.; El-din, N.K.B.; Abou-el-magd, R.F. 2015. Antioxidant and hepatoprotective activities of grape seeds and skin against 
Ehrlich solid tumor induced oxidative stress in mice. Egyptian Journal of Basic and Applied Sciences, 2: 98-109.

Ballesteros, M.L; Wunderlin, D.A.; Bistoni, M.A. 2209. Oxidative stress responses in different organs of Jenynsia multidentata exposed to endosulfan. Ecotoxicology and Environmental Safety, 72: 199-205.

Bhattacharya, S.; Prasanna, A.; Majumdar, P.; Suresh-Kumar, R.B.; Haldar, P.K. 2011. Antitumor efficacy and amelioration of oxidative stress by Trichosanthes dioica root against Ehrlich ascites carcinoma in mice. Pharmaceutical Biology, 49: 927-935.

Botelho, J.R.S.; Santos, A.G.; Araújo, M.E.; Braga, M.E.M.; GomesLeal, W.; Carvalho Junior, R.N.M.; Meireles, A.A.; Oliveira, M.S. 2015. Copaíba (Copaifera sp.) leaf extracts obtained by $\mathrm{CO}_{2}$ supercritical fluid extraction: Isotherms of global yield, kinetics data, antioxidant activity and neuroprotective effects. Journal of Supercritical Fluids, 98: 167-171.

Bradford, M.M. 1976. A rapid and sensitive method for the quantification of microgram quantities of protein utilizing the principle of protein-dye binding. Analytical Biochemistry, 72: 248-254.

Buege, J.A.; Aust, S.D. 1978. Microsomal lipid peroxidation. Methods in Enzymology, 52: 302-309.

Calixto-Campos, C.; Zarpelon, A.C.; Corrêa, M.; Cardoso, R.D.R.; Pinho-Ribeiro, F.A.; Cecchini, R.; et al. 2013. The Ehrlich's tumor induces pain-like behavior in mice: a novel model of cancer pain for pathophysiological studies and pharmacological screening. Biomedical Research International, 2013: 1 -12.

Cassali, G.D.; Silva, A.E.; Santos, F.G.A. 2006. Marcadores de proliferação celular na avaliação do crescimentodo tumor sólido e ascítico de Ehrlich. Arquivo Brasileiro de Medicina Veterinária e Zootecnia, 58: 658-661.

Costa, J.A.S. 2018. Copaifera in Flora do Brasil 2020 em construção. Jardim Botânico do Rio de Janeiro. (http://reflora.jbrj.gov.br/ reflora/floradobrasil/FB22895). Accessed on 23 Aug 2018.

Das, M.K.; Mukkanti, K.; Rao, G.S.; Sahu, P.K.; Silpavathi, L. 2014. Evaluation of antitumor and antioxidant potential of a polyherbal extract on Ehrlich's ascites carcinoma xenografted mice. Journal of Pharmacy and Nutrition Sciences, 4: 20-26.

Ehrlich, P.; Apolant, H. 1905. Beobachtungen über maligne Mausetumoren. Berliner klinische Wochenschrift, 42: 871-874.

Frajacomo, F.T.T.; Padilha, C.S.; Marinello, P.C.; Guarnier, F.A.; Cecchini, R.; Duarte, J.A.R.; Deminice, R. 2016. Solid Ehrlich carcinoma reproduces functional and biological characteristics of cancer cachexia. Life Sciences, 162: 47-53.

Furtado, R.A.; de Oliveira, P.F.; Senedese, J.M.; Ozelin, S.D.; de Souza, L.D.R.; Leandro, L.F.; et al. 2018. Assessment of toxicogenetic activity of oleoresins and leaves extracts of six Copaifera species for prediction of potential human risks. Journal of Ethnopharmacology, 221: 119-125.

Gomes, N.M.; Rezende, C.M.; Fontes, S.P.; Hovell, A.M.; Landgraf, R.G.; Matheus, M.E.; Pinto, A.C.; Fernandes, P.D. 2008. Antineoplasic activity of Copaifera multijuga oil and fractions against ascitic and solid Ehrlich tumor. Journal of Ethnopharmacology, 119: 179-184.

Goulart, M.O.F.; Vasconcelos, S.M.L.; Moura, J.B.F.; Benfato, M.S.; Manfredini, V.; Kubota, L.T. 2007. Espécies reativas de oxigênio e nitrogênio, antioxidantes e marcadores de dano oxidativo em sangue humano: principais métodos analíticos para sua determinação. Química Nova, 30: 1323-1338.

Gramosa, N.V.; Silveira, E.R.; Cavalcanti, B.C.; Ferreira, J.R.; de Oliveira, F.S.; Rao, V.S.; Costa-Lotufo, L.V.; de Moraes, M.O.; Pessoa, C. 2010. Chemistry and pharmacology of Copaifera langsdorffii Desf.: an overview. In: Awaad, A.S.; Govil, J.N.; Singh, V.K. (Ed.). Recent Progress in Medicinal Plants, v. 27 (Drug Plants I). Studium Press LLC, Houston, p.235-260.

Grivennikov, S; Greten, FR; Karin, M. 2010. Immunity, inflammation, and cancer. Cell, 140: 883-899.

Habig, W.H.; Pabst, M.J.; Jacoby, W.B. 1974. Glutathione S-transferase, the first enzymatic step in mercapturic acid formation. Journal of Biological Chemistry, 249: 7130-7139.

Ighodaro, O.M.; Akinloye, O.A. 2017. First line defence antioxidants-superoxide dismutase (SOD), catalase (CAT) and glutathione peroxidase (GPX): Their fundamental role in the entire antioxidant defence grid. Alexandria Journal of Medicine, https://doi.org/10.1016/j.ajme.2017.09.001.

Izumi, E.; Ueda-Nakamura, T.; Veiga Jr., V.F.; Pinto, A.C.; Nakamura, C.V. 2012. Terpenes from Copaifera demonstrated in vivo antiparasitic and synergic activity. Journal of Medicinal Chemistry, 55: 2994-3001.

Kavitha, K.; Manoharan, S. 2006. Anticarcinogenic and antilipidperoxidative effects of Tephrosia purpurea (Linn) pers. In 7, 12-dimethyl benz (a) anthracene (DMBA) induced hamster buccal pouch carcinoma. Indian Journal of Pharmacology, 38: 185-189.

Kroneck, P.M.H.; Sosa-Torres, M.E. 2015. Sustaining Life on Planet Earth: Metalloenzymes Mastering Dioxygen and Other Chewy Gases. Metal Ions in Life Sciences, 15: 1-12

Leandro, L.M.; Vargas, F.S.; Barbosa, P.C.S.; Neves, J.K.O.; Silva, J.A.; Veiga, J.R.; VF. 2012. Chemistry and biological activities of terpenoids from copaiba (Copaifera spp.) oleoresins. Molecules, 17: 3866-3889.

Loaces, D.L.; Luis, I.R.; Cabrera, G.S. 2003. Descubrimiento y desarrollo de agentes anticancerígenos derivados de plantas medicinales. Revista Cubana Plantas Medicinales, 8.

Lushchak, V.I. 2014. Free radicals, reactive oxygen species, oxidative stress and its classification. Chemico-Biological Interactions, 224: 164-175.

Misra, H.P.; Fridovich, I. 1972. The role of superoxide anion in the auto-oxidation o epinephrine and a simple assay for superoxide dismutase. Journal Biological Chemistry, 247: 3170-3175.

Nathiya, S.; Nandhini, A. 2014. Evaluation of antioxidant effect of Salacia oblonga against aluminum chloride induced visceral toxicity in albino rats. International Journal of Basic \& Clinical Pharmacology, 3: 315-319.

Nelson, D.P.; Kiesow, L.A. 1972. Enthalphy of decomposition of hydrogen peroxide by catalase at $25^{\circ} \mathrm{C}$ (with molar extinction coefficients of $\mathrm{H}_{2} \mathrm{O}_{2}$ solution in the UV). Analytical Biochemistry, 49: 474-478.

Noda, N.; Wakasugi, H. 2000. Cancer and oxidative stress, Japan Medical Association Journal, 11: 1571-1574. 
Pereira, D.L.; Da Cunha, A.P.S.; Cardoso, C.R.P.; Da Rocha, C.Q.; Vilegas, W.; Sinhorin, A.P.; Sinhorin, V.D.G. 2018. Antioxidant and hepatoprotective effects of ethanolic and ethyl acetate stem bark extracts from Copaifera multijuga (Fabaceae) in mice. Acta Amazonica, 48: 347-357.

Pinent, M.; Bladé, C.; Salvadó, M.J.; Blay, M.; Pujadas, G.; Fernadézlarrea, J.; Arola, L.; Ardévol, A. 2006. Procyanidin effects on adipocyte-related pathologies. Critical Reviews in Food Science and Nutrition, 46: 543-550.

Rajeshwar, Y.; Gupta, M.; Mazumder, U.K. 2005. Antitumor Activity and in vivo Antioxidant Status of Mucuna pruriens (Fabaceae) Seeds against Ehrlich Ascites Carcinoma in Swiss Albino Mice. Iranian Journal of Pharmacology \& Therapeutics, 4: 46-53.

Reuter, S.; Gupta, S.C.; Chaturvedi, M.M.; Aggarwal, B.B. 2010. Oxidative stress, inflammation, and cancer: how are they linked?. Free Radical Biology \& Medicine, 49: 1603-1616.

Roe, J.H. 1954. Chemical determination of ascorbic, dehydroascorbic, and diketogulonic acids. In: Glick, D. (Ed.). Methods of Biochemical Analysis. v. 1. Interscience, p.115-139.

Samudrala, P.K.; Augustine, B.B.; Kasala, E.R.; Bodduluru, L.N.; Barua, C.; Lahkar, M. 2015. Evaluation of antitumor activity and antioxidante status of Alternanthera brasiliana against Ehrlich ascites carcinoma in Swiss albino mice. Pharmacognosy Research, 7: 66-73.

Santiago, K.B.; Conti, B.J.; Murbach-Teles-Andrade, B.F.; Mangabeira da Silva, J.J.; Rogez, H.L.G.; Crevelin, E.J.; et al. 2015. Immunomodulatory action of Copaifera spp. oleoresins on cytokine production by human monocytes. Biomedical Pharmacotherapy, 70: 12-18.

Guimarães-Santos, A.G.; Santos, D.S.; Santos, I.R.; Lima, R.R.; Pereira, A.; de Moura, L.S.; Carvalho Jr., R.N.; Lameira, O.; Gomes-Leal, W. 2012. Copaiba oil-resin treatment is neuroprotective and reduces neutrophil recruitment and microglia activation after motor cortex excitotoxic injury. Evidence-Based Complementary and Alternative Medicine, 2012: ID 918174.

Schneider, C.D.E.; Oliveira, A.R. 2004. Radicais livres de oxigênio e exercício: mecanismos de formação e adaptação ao treinamento físico. Revista Brasileira de Medicina do Esporte, 10: 87-90.
Sedlack, J.; Lindsay, R.H. 1968. Estimation of total, protein-bound, and nonprotein sulfhydryl groups in tissue with Ellman's reagent. Analytical Biochemistry, 25: 192-205.

Sellés, A.J.N.; Rossi, W.M.; Garrido, G. 2016. Biomarcadores del estrés oxidativo en la terapia antioxidante. Journal of Pharmacy and Pharmacognosy Research, 4: 62-83.

Senedese, J.M.; Alves, J.M.; Lima, I.M.S.; Andrade, E.A.P.; Furtado, R.A.; Bastos, J.K.; Tavares, D.C. 2013. Chemopreventive effect of Copaifera langsdorffii leaves hydroalcoholic extract on 1,2-dimethylhydrazine-induced DNA damage and preneoplastic lesions in rat colon. BMC Complementary and Alternative Medicine, 13: 1-8.

Silva, J.J.M.; Crevelin, E.J.; Carneiro, L.J.; Rogez, H.; Veneziani, R.C.S.; Ambrósio, S.R.; Moraes, L.A.B.; Bastos, J.K. 2017. Development of a validated ultra-high-performance liquid chromatography tandem mass spectrometric method for determination of acid diterpenes in Copaifera oleoresins. Journal of Chromatograph A, 1515: 81-90.

Vasconcelos, T.B.; Cardoso, A.R.N.R.; Josino, J.B.; Macena, R.H.M.; Bastos, V.P.D. 2014. Radicais livres e antioxidantes: proteção ou perigo? UNOPAR Cientifica, Ciências Biológicas e da Saúde, 16: 213-219.

Veiga Jr., V.F.; Pinto, A.C. 2002. The Copaifera L. genus. Quiimica Nova, 25: 273-286.

Veiga Jr., V.F.; Rosas, E.C.; Carvalho, M.V.; Henriques, M.G.; Pinto, A.C. 2007. Chemical composition and anti-inflammatory activity of copaiba oils from Copaifera cearensis Huber ex Ducke, Copaifera reticulata Ducke and Copaifera multijuga Hayne - a comparative study. Journal of Ethnopharmacology, 112: 248-254.

Yan, L.J; Traber, M.G.; Packer, L. 1995. Spectrophotometric method for determination of carbonyls in oxidatively modified apolipoprotein B of human low-density lipoproteins. Analytical Biochemistry, 228: 349-351.

RECEIVED: $23 / 02 / 2018$

ACCEPTED: 09/08/2018

ASSOCIATE EDITOR: João Vicente Souza 